\title{
Ventriculitis from Acinetobacter calcoaceticus variant anitratus
}

\author{
R A M Y O G V \\ From the Division of Infectious Disease, The Children's Memorial Hospital, Chicago, Illinois, USA
}

SUMMARY Ventriculitis from infection with Acinetobacter calcoaceticus variant anitratus occurred in an infant two weeks after surgical repair of a lumbosacral meningomyelocele and ventriculoperitoneal shunting. Recovery took place on replacing the shunt with an extraventricular deviation device and giving gentamicin and ampicillin intravenously.

Acinetobacter calcoaceticus variant anitratus (syn $\mathrm{B}_{5} \mathrm{~W}$, Bacterium anitratum, Herellea vaginicola) is a short Gram-negative pleomorphic rod which is widely distributed in nature (Baumann, 1968) and frequently colonises various sites in humans (Rosenthal, 1974). Several clinical reviews (Robinson et al., 1964; Glew et al., 1977) describe the range of infections caused by this bacterium which include respiratory and urinary tract infections, septicaemia, endocarditis, and abscesses in different sites. Infections of the central nervous system are seldom reported. Most infections occur in old patients, patients with severe or chronic diseases, or after surgery, instrumentation, and antibiotic treatment. We recently saw a neonate who developed ventriculitis from $A$. calcoaceticus variant anitratus.

\section{Case report}

A baby girl (HK) was admitted to Children's Memorial Hospital at 7 hours of age for repair of a lumbosacral meningomyelocele. The pregnancy and delivery had been normal. On admission, she was alert, with head circumference of $335 \mathrm{~mm}$, and a soft anterior fontanelle $(20 \times$ $20 \mathrm{~mm}$ ). There was a full range of passive movement in the lower extremities and anal hypotonia. An intact lumbosacral meningomyelocele was noted. She underwent surgical reconstruction of the spinal cord and repair of the meningomyelo-

Address for reprint requests: Dr Ram Yogev, Division of Infectious Disease, The Children's Memorial Hospital, 2300 Children's Plaza, Chicago, Illinois 60614, USA.

Accepted 10 November 1978 cele. A week after surgery, the anterior fontanelle was noted to be full, and some leakage from the repair site was found. Hydrocephalus was seen on angiography. A right ventriculoperitoneal (VP) shunt was placed, but had to be revised a week later because the peritoneal tip was plugged. A week later the child developed fever $\left(38.5^{\circ} \mathrm{C}\right)$ and again the anterior fontanelle became full. The shunt was removed and a left extraventricular deviation (EVD) device was placed. The ventricular fluid had $16 \mathrm{WBC} / \mathrm{mm}^{3}(100 \%$ mononuclear cells), a protein level of $0.21 \mathrm{~g} / 1$ and a glucose level of $2.4 \mathrm{mmol} / 1$. Cultures of the CSF from the time of surgery and the first two days after operation were negative. On the third day, the peripheral WBC increased from 12300 to $23000 /$ $\mathrm{mm}^{3}$ (43\% polymorphonuclear, $26 \%$ bands), the ventricular fluid became turbid demonstrating 2645 white blood cells per $\mathrm{mm}^{3}(75 \%$ polymorphonuclear leucocytes and $25 \%$ mononuclear leucocytes) with protein level of $2.58 \mathrm{~g} / 1$ and glucose level of $2.3 \mathrm{mmol} / 1$. However, she remained clinically well. Cultures grew $A$. calcoaceticus variant anitratus. With the Kirby-Bauer disc method, the bacterium was sensitive to polymyxin $B$, tetracycline, kanamycin, and gentamicin. Treatment was begun with intravenous gentamicin $7.5 \mathrm{mg} /$ $\mathrm{kg} / \mathrm{day}$ and ampicillin $300 \mathrm{mg} / \mathrm{kg} / \mathrm{day}$. For the next six days the cultures remained positive although there was marked improvement in the ventricular fluid with the protein level decreasing to $0.43 \mathrm{~g} / 1$ and cell count to $8 \mathrm{WBC} / \mathrm{mm}^{3}$. After the EVD was replaced on the ninth day, the cultures became negative and remained so for the next 10 days. Antibiotics were stopped, and after three days of negative cultures, a new VP shunt was placed. 


\section{Discussion}

A. calcoaceticus variant anitratus was first described by Debord in 1939, as Herellea vaginicola. This is a Gram-negative coccobacillus which grows well on most media aerobically, does not ferment $1 \%$ lactose, but forms acid without gas in $10 \%$ lactose. Nitrates are not reduced to nitrites and it is non-motile (Daly et al., 1962; Lothe and Griffin, 1965). On Gram-staining this bacterium is sometimes confused with Neisseria meningitidis when diplococcal forms predominate. The presence of long filaments or rods in association with Gramnegative diplococci suggest $A$. calcoaceticus variant anitratus.

In reviewing the English literature, 12 cases of infections of the CNS with $A$. calcoaceticus have been reported (Table). Ten cases of meningitis occurred in patients ranging in age from 4 days to 57 years. Four of them died. One patient had a cerebral abscess and one had ventriculitis.

The pathogenesis of the illness in this child may be similar to shunt infections caused by Staphylococcus epidermidis. Bayston and Lari (1974) showed that $S$. epidermidis frequently colonises the scalp and may be found in the incision site despite meticulous preoperative skin cleansing. This observation suggests that $S$. epidermidis ventriculitis after shunt procedures results from trans-

Table CNS infections caused by acinetobacter calcoaceticus variant anitratus

\begin{tabular}{|c|c|c|c|c|c|}
\hline $\begin{array}{l}\text { Case } \\
\text { number }\end{array}$ & Age & Sex & Disease & Outcome & Reference \\
\hline 1 & 1 year & $\mathbf{F}$ & Meningitis & Recovered & $\begin{array}{l}\text { Lothe and } \\
\text { Griffin } \\
\text { (1965) }\end{array}$ \\
\hline 2 & 1 month & $\mathbf{M}$ & Meningitis & Recovered & $\begin{array}{l}\text { Lothe and } \\
\text { Griffin } \\
\text { (1965) }\end{array}$ \\
\hline 3 & 4 days & $\mathbf{F}$ & Meningitis & Recovered & $\begin{array}{l}\text { Watson } \\
\text { (1957) }\end{array}$ \\
\hline 4 & 6 days & $\mathbf{M}$ & Meningitis & Died & $\begin{array}{l}\text { Watson } \\
\text { (1957) }\end{array}$ \\
\hline 5 & NR & NR & Meningitis & Died & $\begin{array}{l}\text { Ray et al. } \\
\text { (1951) }\end{array}$ \\
\hline 6 & NR & NR & Meningitis & Died & $\begin{array}{l}\text { Ray et al. } \\
\text { (1951) }\end{array}$ \\
\hline 7 & NR & NR & Meningitis & Recovered & $\begin{array}{l}\text { Ray et al. } \\
\text { (1951) }\end{array}$ \\
\hline 8 & 57 years & $\mathbf{F}$ & Meningitis & Recovered & $\begin{array}{l}\text { Green } \\
(1960)\end{array}$ \\
\hline 9 & 55 years & $\mathbf{M}$ & Meningitis & Recovered & $\begin{array}{l}\text { Daly et al. } \\
\text { (1962) }\end{array}$ \\
\hline 10 & 29 years & $\mathbf{M}$ & Meningitis & Died & $\begin{array}{l}\text { Daly et al. } \\
\text { (1962) }\end{array}$ \\
\hline 11 & 65 years & $\mathbf{M}$ & Ventriculitis & NR & $\begin{array}{l}\text { Daly et al. } \\
\text { (1962) }\end{array}$ \\
\hline 12 & 28 years & $\mathbf{M}$ & $\begin{array}{l}\text { Cerebral } \\
\text { abscess }\end{array}$ & Died & $\begin{array}{l}\text { Waage } \\
\text { (1953) }\end{array}$ \\
\hline
\end{tabular}

$\mathrm{NR}=$ not reported. mission of bacteria from the skin into the ventricles during the operation. A. calcoaceticus is a frequent coloniser of the skin (Taplin et al., 1963; Greer et al., 1965) and an analogous sequence of events would explain the pathogenesis of our patient's ventriculitis.

The choice of antibiotic should be based on in vitro susceptibility tests and the ability of the drug to cross the blood-brain barrier. Sensitivity patterns have been variable with ampicillin, sulphonamides, tetracyclines, and streptomycin. Almost all strains of $A$. calcoaceticus have been found to be resistant to penicillin and chloramphenicol (Daly et al., 1962; Glew et al., 1977). Most studies have demonstrated susceptibility to polymyxin B, colistin, kanamycin, gentamicin, and minocyclin. Glew et al. (1977) reported that carbenicillin and an aminoglycoside are synergistic for most strains which were resistant to aminoglycosides alone. Therefore, it seems that the most reliable antimicrobial agents for $A$. calcoaceticus infections are aminoglycosides alone or in combination with carbenicillin.

A. calcoaceticus is a rare cause of central nervous system infections, but if this bacterium is growing from cerebrospinal fluid after head surgery or injury (Deacon, 1945) it should be con₹ sidered as the pathogen and appropriate antibioti treatment started.

I would like to acknowledge the Division of Neurosurgery of The Children's Memorial Hospital for allowing me to study this patient.

\section{References}

Baumann, P. (1968). Isolation of acinetobacter from soil and water. Journal of Bacteriology, 96, 39-42.

Bayston, R., and Lari, J. (1974). A study of the sources of infection in colonised shunts. Developmental Medicine and Child Neurology, 16 (supplement 32), 16-22.

Daly, A. K., Postic, B., and Kass, E. H. (1962). Infections due to organisms of the genus herellea. Archives of Internal Medicine, 110, 580-591.

Deacon, W. E. (1945). A note on the tribe mimeae (Debord). Journal of Bacteriology, 49, 511-512.

Glew, R. H., Moellering, R. C., and Kunz, L. J. (1977). Infections with Acinetobacter calcoaceticus (Herellea vaginicola): clinical and laboratory studies. Medicine (Baltimore), 56, 79-97.

Green, J. D. (1960). Bacterium anitratum meningitis: report of a case and a review of the literature. Archives of Internal Medicine, 106, 870-873.

Greer, J. E., Nikhail, G R., and Livingood, C. S. $\mathrm{\omega}$ (1965). Incidence of mima and herellea on human skin. Bacteriological Proceedings, 1159, 49-52. 
Lothe, F., and Griffin, E. (1965). Bacterium anitratum and Mima polymorpha infection in Uganda. Journal of Clinical Pathology, 18, 301-306.

Ray, T. E., Craig, G., and Silverthorne, N. (1951). Severe infections due to organism $\mathrm{B}_{5} \mathrm{~W}$ (Bacterium anitratum). Canadian Journal of Public Health, 42, 71-72.

Robinson, R. G., Garrison, R. G., and Brown, R. W. (1964). Evaluation of the clinical significance of the genus herellea. Annals of Internal Medicine, 60, 19-27.

Rosenthal, S. L. (1974). Sources of pseudomonas and acinetobacter species found in human culture materials. American Journal of Clinical Pathology, 62, 807-811.

Taplin, D., Rebell, G., and Zaias, N. (1963). The human skin as a source of mima-herellea infections. Journal of the American Medical Association, 186, 952-955.

Waage, R. (1953). Bacterium anitratum $\left(\mathbf{B}_{5} \mathrm{~W}\right)$ isolated from cerebral abscesses. Acta Pathologica Microbiologica Scandinavica, 33, 268-270.

Watson, D. G. (1957). Purulent neonatal meningitis: a study of forty-five cases. Journal of Pediatrics, 50, 352-360. 